\title{
INDIKATOR USER SATISFACTION DALAM APLIKASI E-LECTURE (VIDEO PEER-EVALUATION PADA ONLINE CBL)
}

\author{
Diah Aryani ${ }^{1}$ \\ Muhamad Yusup ${ }^{2}$ \\ Ilamsyah $^{3}$ \\ Dosen Jurusan Sistem Komputer STMIK Raharja ${ }^{1}$, Dosen Jurusan Teknik Informatika STMIK \\ Raharja $^{2}$, Dosen Jurusan Sistem Komputer STMIK Raharja ${ }^{3}$ \\ E-mail: 1diah.aryani@raharja.info, 2yusup@ raharja,info,,3ilamsyah@ raharja.info
}

Diterima: 2 Juli 2018/ Disetujui : 18 Juli 2018

\begin{abstract}
Currently, the learning process of more interactive e-learning method in college becomes a necessity, but the current e-learning learning method still uses the Teacher Centred Learning (TCL) approach. Of course, this TCL approach is less relevant for its high use of curriculum that refers to the National Qualification Framework (KKNI) so it is necessary to integrate into a more active and interactive approach that is Collaborative Learning (CbL) approach. CbL's approach to the implementation of the student becomes more active in developing knowledge and learning skills so as to create a more cooperative, supportive and cooperative classroom climate. Implementation of e-learning with $\mathrm{Cbl}$ approach, students in collaboration with their groups and exposing presentation materials online in the form of presentation videos by each group and other groups directly assess the presentation to each member of the presentation group. Usability analysis of video peer evaluation application on CbL online using user satisfaction focused on usability aspect analysis where user acting as Video Peer-Evaluation application user. In this research, the method of analysis using Structural Equation Modeling (SEM) or structural equation model is a multivariate analysis that is used to analyze relationships between variables in a complex manner. the main requirement of using SEM is to design hypothesis model by using structural model and measurement model in the form of path diagram. It is hoped that this research can remind the satisfaction that can be used to measure the success of Video Peer Evoluation application in online colaborative learning.
\end{abstract}

Keywords: Teacher Centered Learning (TCL), Collaborative Learning (CbL), Sctuctural Equation Modeling (SEM)

\begin{abstract}
ABSTRAK
Saat ini proses pembelajaran metode e-learning yang lebih interaktif di perguruan tinggi menjadi sebuah keharusan, namun metode pembelajaran e-learning yang berjalan masih mempergunakan pendekatan Teacher Centred Learning (TCL). Tentunya pendekatan TCL ini kurang relevan pelaksanaannya bagi perguuan tinggi yang mengunakan kurikulum yang mengacu pada Kerangka Kualifikasi Nasional Indonesia (KKNI) sehingga perlu megintegrasi ke pendakatan yang lebih aktif dan interaktif yaitu pendekatan Collabolative Learning (CbL). Pendekatan CbL pelaksanaannya mahasiswa menjadi lebih aktif dalam mengembangkan pengetahuan dan keterampilan pembelajaran sehingga tercipta iklim perkuliahan yang lebih kolaboratif, supportif dan kooperatif. Implementasi elearning dengan pendekatan Cbl, mahasiswa bekerjasama dengan kelompoknya serta memaparkan materi presentasi secara online dalam bentuk video presentasi oleh setiap kelompok dan kelompok lainnya langsung menilai presentasi ke setiap anggota kelompok yang presentasi. Analisa usability aplikasi video peer evaluation pada online CbL menggunakan user satisfaction difokuskan pada analisis aspek usability dimana pengguna yang berperan sebagai pengguna aplikasi Video PeerEvaluation. Pada penelitan ini metode analisa menggunakan Structural Equation Modeling (SEM) atau model persamaan struktural merupakan analisis multivariate yang dipergunakan melakukan
\end{abstract}


analisa hubungan antar variable secara kompleks. persyaratan utama mempergunakan SEM yaitu untuk merancang model hipotesis dengan mempergunakan model struktural dan model pengukuran dalam bentuk diagram jalur. Diharapkan penelitian ini dapat meningatkan kepuasanyang dijadikan tolak ukur keberhasilan aplikasi Video Peer Evoluation pada online colaborative learning.

Kata kunci: Teacher Centered Learning (TCL), Collaborative Learning (CbL), Sctuctural Equation Modeling (SEM)

\section{PENDAHULUAN}

Sesuai Permendikbud No. 49 tahun 2014 tentang Standar Nasional Pendidikan Tinggi, semua Program Studi dituntut menghasilkan lulusan yang sesuai standar minimal dalam kualifikasi KKNI (Kerangka Kualifikasi Nasional Indonesia). Kurikulum berstandar KKNI sudah tidak mempergunakan pendekatan Teacher Centered Learning (TCL), dimana pembelajaran berpusat pada Dosen. Sedangkan Pendekatan yang digunakan dalam KKNI adalah Student Centered Learning (SCL) merupakan strategi pembelajaran yang memposisikan mahasiswa sebagai peserta didik (subyek) yang aktif dan mandiri, dengan kondisi psikologik sebagai adult learner, bertanggung jawab sepenuhnya atas pembelajarannya sehingga tercapai kemandirian dalam mendapatkan pengetahuan.

Sistem pembelajaran menuntut mahasiswa untuk menyelesaikan persyaratan antara lain : absensi, tugas mandiri, ujian tengah semester dan ujian akhir semester. Tugas mandiri merupakan tugas dari dosen kepada mahasiswa berupa tugas-tugas yang berkaitan dengan materi-materi mata kuliah yang diampuh. Melalui tugas mandiri, mahasiswa bisa belajar dengan aktif dengan membentuk diskusi antara kelompok, presentasi makalah, latihan-latihan soal dan lain sebagainya sehingga mahasiswa menjadi lebih aktif dalam mengembangkan pengetahuan dan keterampilan pembelajaran sehingga tercipta iklim perkuliahan yang lebih kolaboratif, suportif dan kooperatif.

Dalam proses pembelajaran, setiap dosen dituntut untuk memberikan motivasi mahasiswa untuk mendapatkan pengetahuan, pemahaman, dan penerapan serta analisis atau sintesis dan mengintegrasikan berbagai informasi. Dosen juga harus bisa menciptakan suasana pembelajaran dimana mahasiswa menjadi terlibat aktif. Untuk mencapai tujuan tersebut maka dosen bisa mempergunakan salah satu model pembelajaran SCL, yaitu : Small Group Discussion, Role-Play \& Simulation, Discovery Learning (DL) dan Self-Directed Learning (SDL), Cooperative Learning (CL), Collaborative Learning, Project Based Learning (PjBL) dan Problem Based Learning and Inquiry (PBL).

Dalam penelitian ini, peneliti menganalisa usability aplikasi video peer evaluation pada online $\mathrm{CbL}$ menggunakan user satisfaction difokuskan pada analisis aspek usability dimana pengguna yang berperan sebagai pengguna aplikasi Video Peer-Evaluation dengan metode Collaborative Learning. Untuk memudahkan mendapatkan pemahaman mengenai permasalahan utama yang akan diteliti dalam penelitian ini antara lain :

1. Aspek-aspek yang perlu diperhatikan dalam analisis usabilility terhadap aplikasi video peer evaluation?

2. Variabel-variabel apa saja yang mempengaruhi penerimaan user terhadap aplikasi video peer evaluation dalam kerangka usability?

Dalam penelitian permasalahan tingkat kepuasan user pengguna aplikasi video peer evaluation terdapat beberapa cara, diantaranya adalah sructural equation modeling, multiple logistic regression, partial least square dan generalized maimum entropy (Alamsyah 2008). Dalam penelitian ini tingkat kepuasan pengguna terhadap Aplikasi Video Peer Evaluation akan diukur menggunakan pendekatan structural equation modeling (SEM)

\section{METODE PENELITIAN}

Untuk membangun Sistem Online Collaborative Learning (Online $\mathrm{CbL}$ ) akan menggunakan metode penelitian yang meliputi Metode Pengumpulan Data, Metode Pengembangan Sistem, Arsitektur Sistem Online CbL, teknik pengumpulan data untuk pengembangan sistem, dan 
pengembangan antarmuka pengguna (user interface). Pada penelitian ini melanjutkan dari penelitian sebelumnya yang sudah membahas metode rekayasa piranti lunak yang digunakan menggunakan metode Waterfall, penelitian ini fokus pada pembuatan model indikator user satisfaction dalam Aplikasi Video Peer-Evaluation pada Online CbL. Metode Penelitian ini dapat dilihat jelas pada Gambar 1.

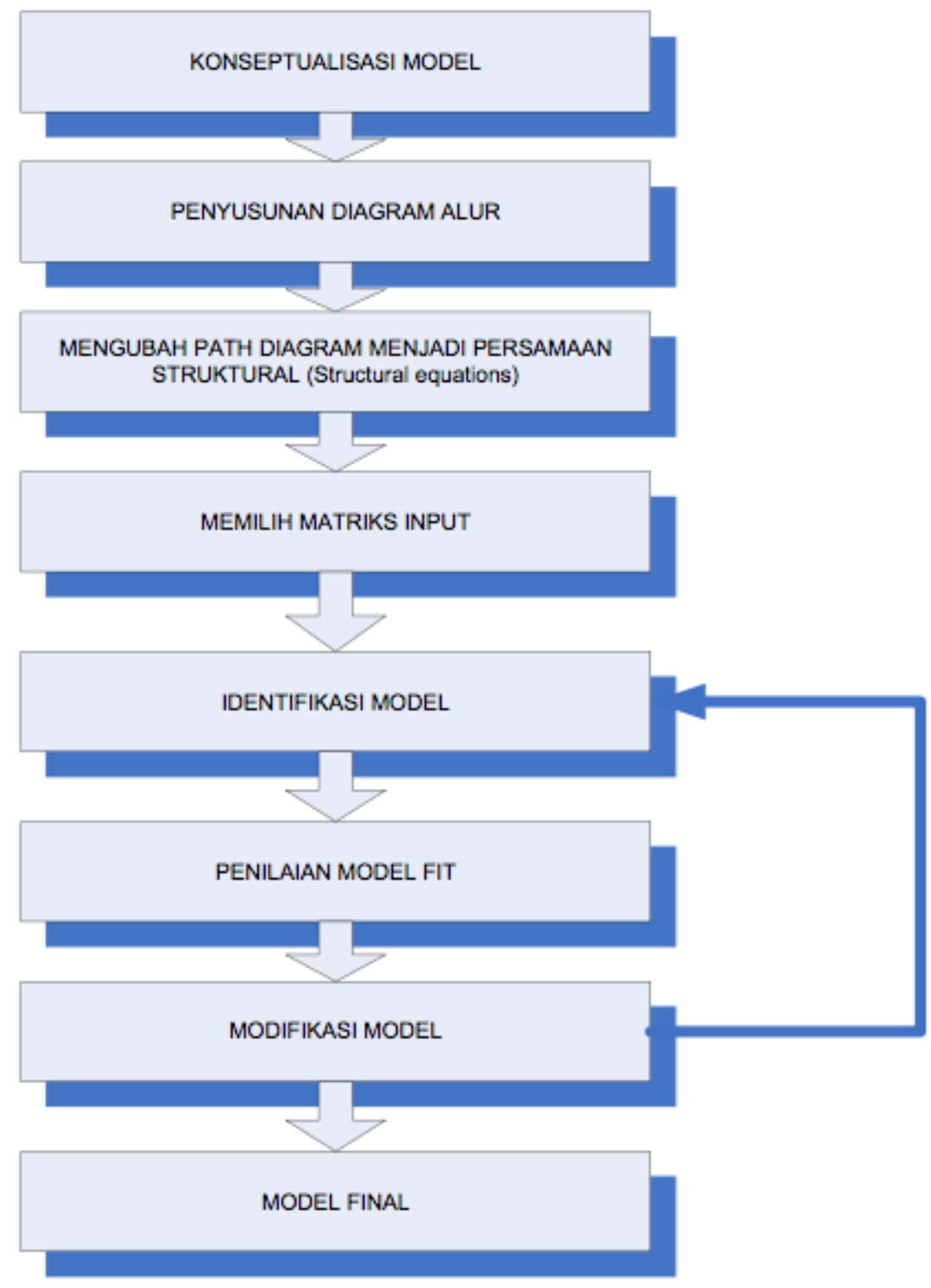

Gambar 1. Alur SEM

\section{Landasan Teori}

Perancangan interaksi sebuah aplikasi biasanya memperhatikan user interface atau tampilan dari sebuah produk sehingga lebih menekankan perancangan sebuah interface yang banyak terkait dengan usability dari sebuah produk. Dan penekanan dalam merancang sebuah interface muka lebih banyak berkaitan dengan Usability dari aplikasi. Apakah interface sebuah aplikasi mudah digunakan? Usability bisa diartikan sebagai proses optimasi interaksi antara pengguna dengan sistem yang dapat dilakukan dengan interaktif, sehingga pengguna mendapatkan informasi yang tepat atau menyelesaikan suatu aktivitas pada aplikasi tersebut dengan lebih baik [1]. suatu aplikasi dapat menjadi efektif, efisien dan memberi kepuasan kepada pengguna, maka aplikasi tersebut harus memberikan kesempatan kepada pengguna dalam mengerjakan aktivitas pada aplikasi tersebut sampai selesai dengan baik. 
Menurut ISO 9241 - 11 (1998), Usability adalah sejauh mana sebuah produk dapat digunakan oleh pengguna tertentu untuk mencapai tujuan tertentu dengan efektif, efisiensi dan pengguna menjadi puas dalam kontek penggunaan. Secara umum pengertian Usability adalah atribut dari kualitas yang digunakan untuk mengevaluasi bagaimana mudahnya sebuah antar muka digunakan.

Menurut buku "Handbook of Usability Testing: How to Plan, Design, and Conduct Effective Test" oleh Jeffrey Rubin dan Dana Chisnell, terdapat lima unsur yang menjadi pokok usabilitas, yaitu; 1) Kegunaan; 2) Efisiensi; 3) Efektivitas; 4) Kepuasan; dan 5) Aksesibilitas. Dalam perkembangan teknologi media baru berbasis internet, halaman web menjadi sentral. Di ruang virtual inilah, para pengguna internet berselancar dan mendapatkan pengalaman berinteraksi dengan perangkat teknologi tersebut. Halaman web bisa sangat variatif menampilkan informasi sesuai layanan yang mereka berikan [2].

Menurut Jacob Nielson [3], beberapa aspek usability testing meliputi lima hal, yaitu:

a. Learnability, menjelaskan tingkat kemudahan pengguna atau user dalam mengerjakan task-task dasar atau saat berhadapan dengan sistem yang ada.

b. Efficiency, menjelaskan waktu yang dibutuhkan pengguna untuk mengerjakan tugas-tugas yang ada saat mereka pertama kali mempelajari sistem tersebut.

c. Memorability, menjelaskan tingkat kemudahan pengguna atau user dalam menggunakan sistem dengan baik, setelah beberapa lama tidak menggunakannya.

d. Errors, menjelaskan kemungkinan terjadinya error atau kesalahan yang dilakukan oleh pengguna dan seberapa mudah mereka dapat mengatasinya.

e. Satisfaction, menjelaskan tentang tingkat kepuasan pengguna dalam menggunakan sistem yang telah dibuat.

\section{Structural Equation Modeling (SEM)}

Structural Equation Modeling (SEM). SEM merupakan perkembangan dari model persamaan berganda (regresi) yang dikembangkan dari prinsip ekonometri dan digabungkan dengan prinsip pengaturan (analisis faktor) dari psikologi dan sosiologi. [3]

Yamin dan Kurniawan [4] menjelaskan alasan yang mendasari digunakannya SEM adalah: SEM memiliki kemampuan untuk mengestimasi hubungan antara variabel yang bersifat multiple relationship. Hubungan ini dibentuk dalam model struktural (hubungan antara konstruk laten eksogen dan endogen). SEM memiliki kemampuan untuk menggambarkan pola hubungan antara konstruk laten (unobserved) dan variabel manifest (manifest variabel atau variabel indikator). SEM memiliki kemampuan mengukur besarnya pengaruh langsung, pengaruh tidak langsung, dan pengaruh total antara konstruk laten (efek dekomposisi).

\section{Literature Review}

1. Open Learning Optimization Based on Cloud Technology: Case Study Implementation in Personalization E-learning yang ditulis oleh Nungki Selviandro, Mira Suryani, Zainal A. Hasibuan. Dimana Penelitian ini menyatakan bahwa desain dari Arsitektur yang diusulkan terdiri dari enam lapisan: (1) Infrastructure,(2) Platform, (3) Application, (4) Service, (5) Akses, (6) User. Penelitian ini mendorong pengembangan konsep Indonesia Open Educational Resources (IOER) dengan mengadopsi konsep Cloud Computing.[5]

2. Cloud-Based E-Learning: A Proposed Model and Benefits by Using E-Learning Based on Cloud Computing for Educational Institution ditulis oleh Nungki Selviandro, Zainal A.Hasibuan di dalam penelitian ini mengusulkan arsitektur e-learning berbasis Cloud Computing terdiri dari 5 layer: 1) layer Infrastruktur, 2) layer platform, 3) layer application, 4) layer Access, 5) layer User. Tiga layer pertama adalah layer dasar dari Cloud Computing, dan penulis menambahkan dua layer baru yaitu Access Layer dan User Layer. Access Layer untuk membedakan peralatan yang mengakses sistem ini, sedangkan User Layer untuk membedakan institusi pendidikan yang akan menggunakan e-learning berbasis Cloud Computing.[6]

3. Indikator User Satisfaction dalam Layanan E-Learning oleh Devi Lestari dan Nurhadi Waryanto, penelitian ini membahas tentang Structural Equation Modeling (SEM) atau model persamaan struktural merupakan analisis multivariate yang digunakan untuk menganalisis hubungan antar 
variabel secara kompleks sehingga menghasilkan penelitian tingkat kepuasan ini dapat menjadi tolak ukur keberhasilan layanan e-learning (Be smart) yang dapat membantu pengembangan $e$ learning (Be Smart) lebih optimal.[7]

\section{HASIL DAN PEMBAHASAN}

\section{Model SEM}

Model SEM yang dijelaskan oleh masing-masing variabel independen maupun variabel dependen yang digunakan indikator user satisfaction terdiri dari:

1. Variabel Independen (Variabel bebas)

\section{$\mathrm{X} 1$ : isi (content)}

Variabel ini menjelaskan pandangan responden terhadap informasi yang tersedia pada aplikasi e-Lecture (Video Peer-Evaluation pada Online CbL). Variabel ini untuk mengukur item-item informasi yang ada pada aplikasi ini, tampilan grafis, menu, fitur dan lainnya. Terdapat 5 butir yang diukur menggunakan Skala Likert.

Kisi-Kisi konstruks X1: Isi (content)

\begin{tabular}{|l|c|c|}
\hline \multicolumn{1}{|c|}{ Indikator } & Variabel & Butir \\
\hline Tampilan grafis aplikasi -Lecture menarik & $\mathrm{X} 1.1$ & 1 \\
\hline $\begin{array}{l}\text { Menu dan fitur pada Aplikasi } \text {-Lecture lengkap untuk } \\
\text { memenuhi kebutuhan perkuliahan. khususnya untuk } \\
\text { kolaborasi } \text { online. }\end{array}$ & $\mathrm{X} 1.2$ & 2 \\
\hline $\begin{array}{l}\text { Terdapat fitur tugas-tugas kelompok pada e-Lecture } \\
\text { hasil dari penyelesaian tugas }\end{array}$ & $\mathrm{X} 1.3$ & 3 \\
\hline $\begin{array}{l}\text { Dalam Aplikasi e-Lecture terdapat fasilitas mengirim } \\
\text { tugas. }\end{array}$ & $\mathrm{X} 1.4$ & 5 \\
\hline $\begin{array}{l}\text { Aplikasi e-Lecture ini membuat peserta didik aktif } \\
\text { melakukan eksperimentasi pembelajaran. }\end{array}$ & $\mathrm{X} 1.5$ & \\
\hline
\end{tabular}

X2: akurasi (accuracy)

Variabel ini menjelaskan tentang persepsi responden terhadap informasi yang disajikan dalam Aplikasi e-Lecture, kesesuaian Aplikasi dengan peruntukannya yaitu untuk assesment secara bersamaan dan terbuka untuk pembelajaran kolaborasi. Variabel ini diukur sebanyak 5 butir dengan pernyataan menggunakan skala Likert. 
Kisi-Kisi konstruks X2: Akurasi (accuracy)

\begin{tabular}{|l|c|c|}
\hline \multicolumn{1}{|c|}{ Indikator } & Variabel & Butir \\
\hline $\begin{array}{l}\text { Informasi yang disajikan dalam Aplikasi e-Lecture } \\
\text { sesuai dengan silabus mata kuliah tatap muka. }\end{array}$ & X2.1 & 6 \\
\hline $\begin{array}{l}\text { Hasil nilai tugas yang disajikan dalam Aplikasi e- } \\
\text { Lecture telah sesuai penghitungannya tepat }\end{array}$ & $\mathrm{X} 2.2$ & 7 \\
\hline $\begin{array}{l}\text { Tugas/Quiz yang diberikan sesuai materi yang } \\
\text { diberikan dan tidak melebar ke pembahasan dan } \\
\text { sesuai dengan silabus perkuliahan. }\end{array}$ & $\mathrm{X} 2.3$ & 9 \\
\hline $\begin{array}{l}\text { Dalam Aplikasi e-Lecture, proses pembelajaran dan } \\
\text { penilaian (assessment) dilakukan secara bersamaan } \\
\text { dan terbuka. }\end{array}$ & $\mathrm{X} 2.4$ & 10 \\
\hline $\begin{array}{l}\text { Aplikasi e-Lecture ini sangat sesuai untuk } \\
\text { pembelajaran kolaborasi. }\end{array}$ & $\mathrm{X} 2.5$ & \\
\hline
\end{tabular}

X3: bentuk (format)

Variabel ini menjelaskan tentang persepsi responden terhadap bentuk dan tata letak yang terdapat pada Aplikasi $e$-Lecture, yang diukur dengan 2 butir pernyataan menggunakan Skala Likert.

Kisi-Kisi konstruks X3: Format

\begin{tabular}{|l|c|c|}
\hline \multicolumn{1}{|c|}{ Indikator } & Variabel & Butir \\
\hline $\begin{array}{l}\text { Layout menu-menu modul Aplikasi e-Lecture } \\
\text { terstruktur dan nyaman dilihat dan mudah digunakan. }\end{array}$ & X3.1 & 11 \\
\hline $\begin{array}{l}\text { Ukuran teks dan warna pada Aplikasi e-Lecture } \\
\text { terstruktur sehingga nyaman untuk dilihat. }\end{array}$ & X3.2 & 12 \\
\hline
\end{tabular}

X4: Kemudahan Pengguna (ease of use)

Variabel ini menjelaskan tentang persepsi responden bahwa Aplikasi e-Lecture dapat diakses dengan mudah oleh pengguna. Variabel ini diukur melalui 6 butir dengan Skala Likert. 
Kisi-Kisi konstruks X4: Kemudahan Pengguna (ease of use)

\begin{tabular}{|l|c|c|}
\hline \multicolumn{1}{|c|}{ Indikator } & Variabel & Butir \\
\hline $\begin{array}{l}\text { Aplikasi e-Lecture mudah diakses dari semua } \\
\text { perangkat (laptop dan perangkat mobile) }\end{array}$ & $\mathrm{X} 4.1$ & 13 \\
\hline $\begin{array}{l}\text { Tampilan layout e-Lecture mudah dipahami } \\
\text { kegunaannya }\end{array}$ & $\mathrm{X} 4.2$ & 14 \\
\hline $\begin{array}{l}\text { Mudah dalam memilih atau masuk ke dalam mata } \\
\text { kuliah yang diinginkan dalam Aplikasi e-Lecture. }\end{array}$ & $\mathrm{X} 4.3$ & 15 \\
\hline $\begin{array}{l}\text { Mudah dalam melakukan upload tugas dalam bentuk } \\
\text { video. }\end{array}$ & $\mathrm{X} 4.4$ & 17 \\
\hline $\begin{array}{l}\text { Mudah dalam melakukan pengaturan user account } \\
\text { pada aplikasi e-Lecture (seperti mengubah data } \\
\text { pribadi, memasang foto, mengganti password dan } \\
\text { lain-lain) }\end{array}$ & $\mathrm{X} 4.5$ & \\
\hline
\end{tabular}

X5: Keamanan dan Privasi (security and privacy)

Variabel ini menjelaskan tentang persepsi responden bahwa Aplikasi e-Lecture harus mampu memberikan keamanan dan dapat melindungi data pengguna yang bersifat pribadi dan rahasia. Terdapat 3 butir yang dapat diukur dengan Skala Likert

Kisi-Kisi konstruks X5: Keamanan dan Privasi (security and privacy)

\begin{tabular}{|l|c|c|}
\hline \multicolumn{1}{|c|}{ Indikator } & Variabel & Butir \\
\hline $\begin{array}{l}\text { Adanya username dan password yang digunakan } \\
\text { untuk login ke dalam Aplikasi e-Lecture untuk akses } \\
\text { keamanan. }\end{array}$ & X5.1 & 18 \\
\hline $\begin{array}{l}\text { Adanya akses time out pada Aplikasi } \text { e-Lecture ketika } \\
\text { tidak dioperasikan dan } \text { outstanding pada waktu } \\
\text { tertentu. }\end{array}$ & X5.2 & 19 \\
\hline $\begin{array}{l}\text { Privasi pengguna benar-benar terjaga dari pengguna } \\
\text { yang tidak berwenang dalam Aplikasi } \text { e-Lecture. }\end{array}$ & X5.3 & 20 \\
\hline
\end{tabular}

X6: Kecepatan Respon Media (Speed of platform response)

Variabel ini menjelaskan tentang persepsi dari responden terhadap Aplikasi e-Lecture terhadap kecepatan akses, download dan upload. Terdapat 3 butir pernyataan dengan menggunakan Skala Likert. 
Kisi-Kisi konstruks X6: Kecepatan Respon Media (Speed of platform response)

\begin{tabular}{|l|c|c|}
\hline \multicolumn{1}{|c|}{ Indikator } & Variabel & Butir \\
\hline $\begin{array}{l}\text { Aplikasi } e \text {-Lecture memiliki respon loading yang } \\
\text { cepat ketika login maupun logout. }\end{array}$ & X6.1 & 21 \\
\hline $\begin{array}{l}\text { Ketika pengguna melakukan klik terhadap menu pada } \\
\text { Aplikasi } \text {-Lecture secara cepat akan mengantarkan } \\
\text { pengguna pada konten pilihan yang dimaksud (waktu } \\
\text { loading halaman baru tidak membutuhkan waktu yang } \\
\text { lama) }\end{array}$ & $\mathrm{X} 6.2$ & 22 \\
\hline $\begin{array}{l}\text { Mengupload tugas kuliah menggunakan Aplikasi } e- \\
\text { Lecture prosesnya cepat. }\end{array}$ & $\mathrm{X} 6.3$ & 23 \\
\hline
\end{tabular}

2. Variabel dependen (variabel terikat)

Y: Kepuasan pengguna (user satisfaction)

Variabel ini menjelaskan respon user atau pengguna terhadap aplikasi e-Lecture video peer dapat menunjukkan keberhasilan terhadap penerapan pada online CbL. Variabel ini diukur melalui butir-butir pernyataan dengan menggunakan skala likert.

Kisi-Kisi konstruks Y: Kepuasan Pengguna (user satisfaction)

\begin{tabular}{|l|c|c|}
\hline \multicolumn{1}{|c|}{ Indikator } & Variabel & Butir \\
\hline $\begin{array}{l}\text { Saudara puas dengan aplikasi e-Lecture dengan video } \\
\text { peer-evaluation pada online CbL ini. }\end{array}$ & Y1.1 & 24 \\
\hline $\begin{array}{l}\text { Aplikasi e-Lecture ini dapat dikatakan berhasil } \\
\text { diterapkan untuk video peer-evaluation pada online } \\
\text { CbL }\end{array}$ & Y1.2 & 25 \\
\hline
\end{tabular}

Hubungan sebab akibat dari variabel bebas pada satu atau beberapa variabel tergantung merupakan pola hubungan antar variabel yang diteliti. Dan dalam penelitian ini terdapat hubung an yang akan diuji diantaranya adalah: Pengaruh Content (X1) terhadap User Satisfaction (Y), Pengaruh Accuracy (X2) terhadap User Satisfaction (Y), Pengaruh Format (X3) terhadap User Satisfaction (Y), Pengaruh Ease of Use (X4) terhadap User Satisfaction (Y), Pengaruh Security and Privacy (X5) terhadap User Satisfaction (Y), Pengaruh Speed of Platform Response (X6) terhadap User Satisfaction (Y).

Pada SEM terdapat dua bagian yaitu model pengukuran dan model struktural. Model pengukuran mendefinisikan hubungan antar variabel yang terobservasi secara langsung atau disebut sebagai indikator (variabel manifest) dengan variabel laten. Dengan kata lain bahwa model pengukuran ini menyediakan nilai-nilai antara instrumen pengukuran (indikator-indikator) dengan konstruk-konstruk yang dirancang untuk diukur (variabel-variabel laten). Sedangkan model struktural mendefinisikan tentang hubungan antar semua variabel laten. Itu sebabnya model struktural mendefinisikan variabel-variabel laten mana saja yang secara langsung atau tidak langsung mempengaruhi perubahan nilai variabel laten lainnya dalam model.

Model pada penelitian ini adalah dengan analisis faktor dengan menggunakan CFA (Confirmatory Factor Analysis). CFA fokus pada bagaimana serta sejauh mana semua variabel yang diobservasi berhubungan dengan faktor-faktor laten yang mendasarinya. Dengan kata lain, model analisis ini berfokus kepada sejauh mana variabel-variabel yang di observasi ini dihasilkan oleh 
konstruk-konstruk laten yang mendasarinya. Dengan demikian kekuatan semua jalur regresi dari semua faktor tersebut ke arah semua variabel yang diobservasi secara langsung (koefisien regresi) menjadi fokus analisisnya. Oleh karena itu CFA hanya fokus pada hubungan antar faktor-faktor dan semua variabel yang diukur maka dalam perspektif SEM disebut juga measurement model (model pengukuran).

Pada penelitian ini menggunakan LISREL, dimana dalam LISREL membedakan antar variabel laten eksogen dan variabel laten endogen. Variabel laten eksogen adalah sama dengan variabel variabel independen atau variabel bebas yang berperan dalam mengubah nilai variabel yang ada pada variabel-variabel laten lainnya dan sebuah model. Sedangkan variabel endogen adalah sama dengan variabel dependen (variabel tergantung), merupakan variabel yang dipengaruhi oleh variabelvariabel eksogen dalam model baik secara langsung maupun tidak langsung.

Dalam model CFA, model pengukuran di spesifikasi dalam notasi eksogen atau variabel $\mathrm{X}$ dan notasi endogen atau variabel Y. Masing-masing model pengukuran ini didefinisikan dengan menggunakan dua matriks dan dua vektor yaitu 1). satu matriks regresi yang berhubungan dengan variabel laten eksogen $(\Lambda \mathrm{x})$ atau variabel laten endogen $(\Lambda \mathrm{y})$ dengan pengukuran observasi masingmasing. 2) Satu vektor variabel eksogen ( $\xi s)$ atau variabel laten endogen ( $\eta \mathrm{s})$ dan satu vektor kesalahan pengukuran yang berhubungan dengan variabel-variabel yang terobservasi secara langsung atau indikator eksogen $(\delta \mathrm{s})$ dan indikator endogen $(\varepsilon s)$.

Dalam LISREL terdapat 3 model pengukuran. Ketiga model pengukuran tersebut meliputi:

1. Model pengukuran untuk semua variabel $X$

Persamaan model pengukuran untuk semua variabel $\mathrm{X}$ sebagai berikut:

$\mathrm{X}=\Lambda \mathrm{x} \xi+\delta$

persamaan 2.1

2. Model pengukuran untuk semua variabel $Y$

Persamaan model pengukuran untuk semua variabel Y sebagai berikut:

$\mathrm{Y}=\Lambda \mathrm{y} \eta+\varepsilon$

persamaan 2.2

3. Model persamaan struktural

Persamaan untuk model struktural sebagai berikut:

$\mathrm{H}=\mathrm{B} \eta+\Gamma \xi+\zeta$

persamaan 2.3

Berikut ini adalah input file untuk menggambarkan model e-Lecture menggunakan LISREL 8.8 sebagai berikut:

!Indikator User Satisfaction

!Riset Video Peer-Evaluation pada Online CbL

!Initial Model

DA $\mathrm{NI}=6 \mathrm{NO}=200 \mathrm{MA}=\mathrm{CM}$

LA

content accuracy format eou sap spr

$\mathrm{CM}$

25.0704

12.436328 .2021

11.72579 .22818 .7390

13.12878 .12805 .06925 .2317

10.23099 .23493 .43899 .455010 .4890

04.348914 .97327 .56713 .56499 .34125 .7034

MO NX=6 NK=1 LX=FR PH=ST

LK

usersati 


\section{PD}

$\mathrm{OU}$

Interpretasi untuk input file diatas sebagai berikut:

!Indikator User Satisfaction dan !Riset Video Peer-Evaluation pada Online CbL merupakan judul file ini, yaitu "Indikator User Satisfaction dalam Aplikasi e-Lecture (Video PeerEvaluation pada Online CbL)". Selanjutnya !Initial Model merupakan komentar sub judul yang menyatakan bahwa model ini adalah model awal dalam penelitian ini. DA NI $=6 \mathrm{NO}=200$ $\mathrm{MA}=\mathrm{CM}$ menunjukkan data ini terdiri atas 6 variabel yang diobservasi dengan jumlah observasi (data) sebanyak 200, dan matriks yang dianalisis adalah matriks kovarian. LA menunjukkan label content accuracy format eou sap spr menunjukkan ada 6 variabel yang diobservasi secara langsung (variabel manisfest) atau indikator. MO menunjukkan kunci model, $\mathrm{NX}=6$ menunjukan model memiliki 6 variabel terobservasi. $\mathrm{NK}=1$ menunjukkan model mempunyai 1 variabel laten $\mathrm{LX}=\mathrm{FU}, \mathrm{FI} \mathrm{PH}=\mathrm{SY}$,FR, matriks phi merupakan matriks simetris (symmetric matrix) dengan setiap elemennya dikenakan parameter bebas (free parameter). LK merupakan label untuk usersati yang menunjukkan 1 variabel laten Endogen ( $\xi \mathrm{s})$ menunjukkan parameter bebas pada matriks lambda Y. OU menunjukkan keluaran yang kita inginkan.

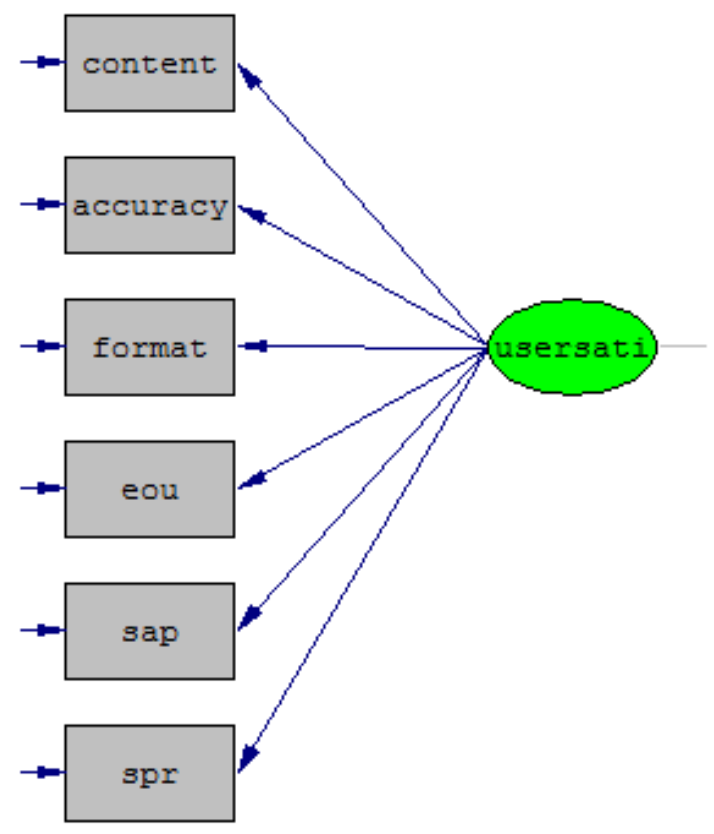

Gambar 2. Jalur untuk SEM 
Ada dua kelompok variabel yang membedakan diagram jalur diatas terdiri dari variabel eksogen diantaranya content, accuracy, format, eou (ease of use), sap (security and privacy) dan spr (speed and platform response). Dan terdapat 1 variabel endogen yaitu usersati (User Satisfaction). Selain itu untuk mengukur variabel tersebut dibuat indikator sebagai variabel manifest digambarkan dalam bentuk oval dan proses pengukuran indikator menjadi variabel dinamakan model pengukuran. Berikut ini adalah model struktur dan model pengukuran yang digambarkan dalam penelitian ini.

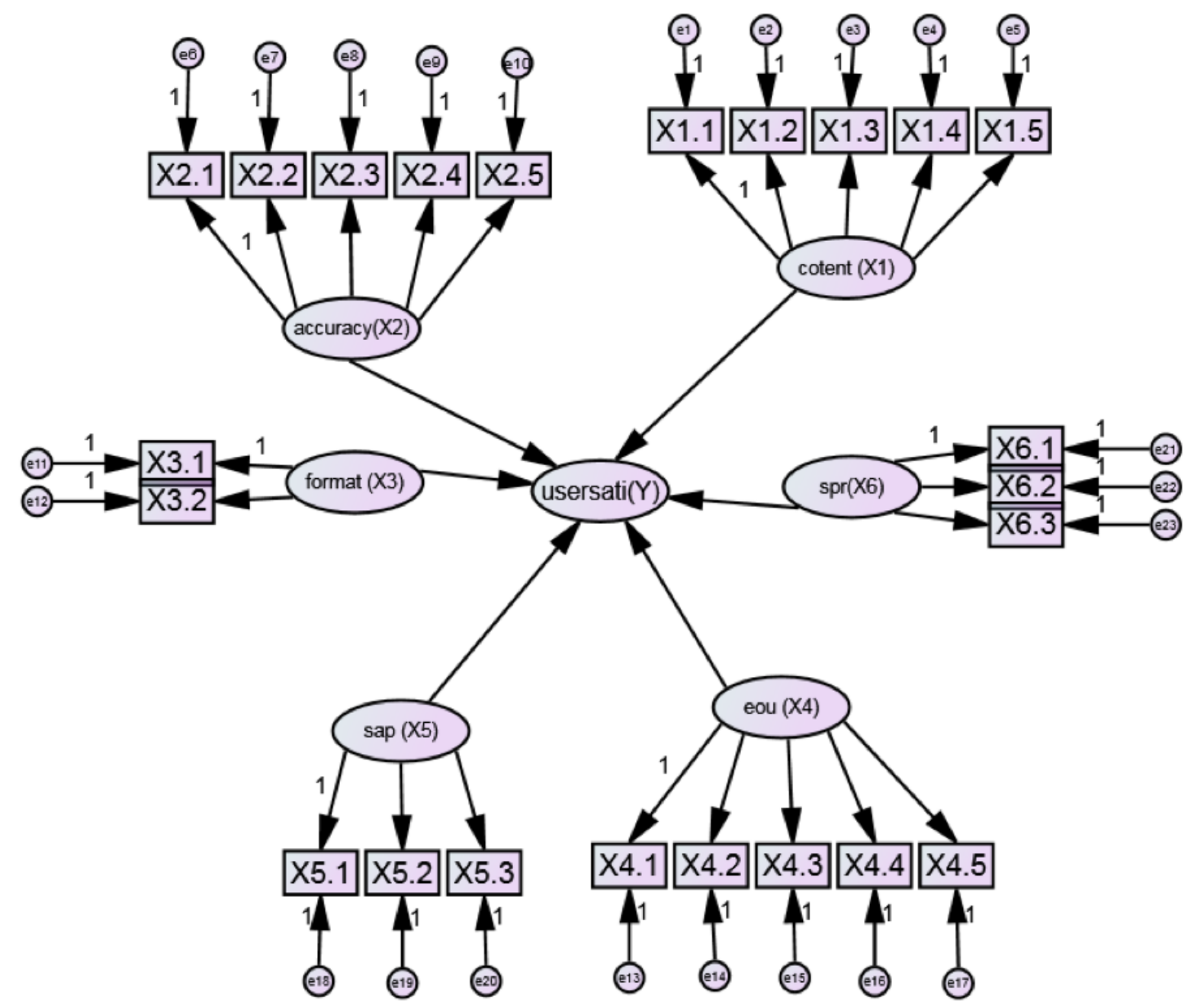

Gambar 3. Model SEM (Structural Equation Model)

Proses konversi dilakukan dari diagram alur ke persamaan struktural dan model pengukuran. Persamaan Struktural untuk menyatakan hubungan kausalitas antar berbagai konstruk sedangkan persamaan model pengukuran harus ditentukan variabel yang mengukur konstruk dan menentukan serangkaian matriks yang menunjukan hubungan yang dihipotesiskan antar kontruk. Adapun persamaan struktural tersebut untuk dicari dan diujikan koefisiennya diantaranya:

$\mathrm{Y} 1=\gamma 1 \mathrm{X} 1+\gamma 2 \mathrm{X} 2+\gamma 3 \mathrm{X} 3+\gamma 4 \mathrm{X} 4+\gamma 5 \mathrm{X} 5+\gamma 6 \mathrm{X} 6+\zeta 1$

keterangan bahwa $\gamma$ adalah konefisien pengaruh variabel eksogen terhadap variabel endogen dan $\zeta$ adalah galat model. 


\section{KESIMPULAN}

Pengembangan Indikator User Satisfaction dalam Aplikasi Video Peer-Evaluation pada Online $C b L$ ini dibangun dengan tujuan akhirnya adalah untuk mendapatkan kepuasan pengguna terhadap aplikasi yang dibangun apapun bentuk dan macam pengukuran. Tingkat atau indeks kepuasan merepresentasikan kepuasan pengguna secara keseluruhan terhadap penggunaan aplikasi Video Peer-Evaluation pada Online CbL.

Adapun indeks yang digunakan dalam penelitian ini adalah menggunakan SEM atau Structural Equation Modeling atau struktural yang menggambarkan analisis multivariate yang digunakan untuk menganalisis hubungan antar variabel. Tahapannya mulai dari konseptual model, menyusun diagram alur, mengubah path diagram menjadi persamaan struktural, memilih matriks input, selanjutnya memodifikasi proses konversi dari diagram alur ke dalam persamaan struktural atau model pengukuran. Dengan penggunaan indikator user satisfaction yang telah disusun ini menggunakan SEM diharapkan dapat menjadi model yang tepat yang digunakan untuk mengukur tingkat kepuasan pengguna dalam pengembangan Aplikasi Video Peer-Evaluation pada Online CbL.

\section{Ucapan Terima Kasih}

Penelitian ini dapat berlangsung dengan baik karena dibiayai oleh Direktorat Riset dan Pengabdian Masyarakat (DRPM), Direktorat Jenderal Penguatan Riset dan Pengembangan Kementerian Riset, Teknologi dan Pendidikan Tinggi (Ristekdikti), oleh karena itu kami mengucapkan terima kasih DRPM - Ristekdikti mengenai pendanaan ini.

\section{Daftar Pustaka}

[1] H.S. Sastramihardja, "Perancangan Kerja dalam Perangkat Lunak, Interaktif," Jurnal Informatika ITB, vol.1, pp. 13-16, 1999.

[2] Joanna. 2010. Penyusunan Usability Index Browser Internet.

[3] D. Hooper, J. Coughlan, and M. R. Mullen, "Structural Equation Modelling: Guidelines for Determining Model Fit Structural Equation Modelling: Guidelines for Determining Model Fit," Electron. J. Bus. Res. Methods, vol. 6, no. 1, pp. 53-60, 2008.

[4] S. Yamin and H. Kurniawan, SPSS Complete: Teknik Analisis Statistik Terlengkap dengan Software SPSS. Penerbit Salemba Jakarta, 2010.

[5] N. Selviandro, M. Suryani, and Z. A. Hasibuan, "Open learning optimization based on cloud technology: Case study implementation in personalization e-learning," 16th Int. Conf. Adv. Commun. Technol., pp. 541-546, 2014.

[6] Nungki Selviandro, Zainal A. Hasibuan. Cloud-Based E-Learning: A Proposed Model and Benefits by Using E-Learning Based on Cloud Computing for Educational Institution.

Information and Communication Technology-EurAsia Conf, tahun 2011

[7] D. Lestari and N. H. Waryanto, "Indikator User Satisfaction Dalam Layanan eLearning," in Seminar Nasional Matematika dan Pendidikan Matematika, 2013, no. November, pp. 978-979. 